\title{
Inclusions in diamonds from Mwadui (Tanzania) - chemical mush in the source
}

Stachel, T. ${ }^{1}$, Harris, J.W. ${ }^{2}$, and Brey, G.P. ${ }^{1}$

1. Institut für Mineralogie, Universität Frankfurt, Senckenberganlage 28, 60054 Frankfurt, Germany

2. Department of Geology \& Applied Geology, University of Glasgow, Glasgow G12 8QQ, Scotland. UK

The Mwadui kimberlite pipe was emplaced on the Tanzania Archon of the Central African Craton (Janse, 1994) during the Eocene (Gobba, 1991 and references therein). Syngenetic inclusions in diamonds from the Mwadui Mine thus may provide insights in the state of the lithospheric upper mantle before the onset of rifting in Eastern Africa in the Miocene (Dawson, 1992).

For the present study an initial population of several thousand diamonds from Mwadui was examined to select a total of 100 stones which then were crushed to release representative mineral inclusions. From their mineral inclusion content Mwadui diamonds can be grouped into peridotitic $(88 \%)$, eclogitic $(2 \%)$, mixed (low-Ca pyrope plus $\mathrm{SiO}_{2}$-phase, $1 \%$ ) and unknown (sulphides, native iron and iron oxides, ferropericlase, dolomite, 9\%) suites. Inclusion chemistry shows Mwadui diamonds to reflect sampling of a lithosphere with an unusually high proportion of undepleted or refertilised mantle peridotite. This is documented mainly by the high ratio of lherzolitic to harzburgitic garnet inclusions (1:2, Fig.1) as well as by the low Mg-numbers of olivines (about 92, Fig. 2) and orthopyroxenes (about 93, Fig.2). High Ni-contents in olivine (mode $0.40 \mathrm{wt} \%$, max 0.43 $\mathrm{wt} \% \mathrm{NiO}$ ) could suggest that this fertility actually represents re-enrichment of a previously depleted source. An explanation may lay in the positive correlation of the proportion of orthopyroxene and the $\mathrm{Ni}$ contents in olivine from peridotitic xenoliths. Kelemen and Hart (1996) interpret this as a metasomatic reaction which creates orthopyroxene at the expense of olivine (which increases the $\mathrm{Ni}$ content of the remaining olivine). Metasomatic enrichment processes may also be indicated by high titanium contents in some lherzolitic and harzburgitic garnets (up to 1.1 wt $\% \mathrm{TiO}_{2}$ ) and orthopyroxenes (up to $0.09 \mathrm{wt} \%$ ).

Application of geothermometers based on garnet-olivine (O'Neill and Wood, 1979, O'Neill, 1980), garnet-opx (Harley, 1984, Brey and Köhler, 1990) and cpx-opx (Brey and Köhler, 1990) equilibria indicate that the mode of equilibration temperatures for Mwadui diamonds lies between $1050-1150{ }^{\circ} \mathrm{C}$. However, the application of various thermometers to the same inclusion-pairs reveals evidence for common disequilibrium between non-touching inclusions. Apparent high temperatures calculated for garnet-opx and garnet-olivine pairs may be attributed to diamond formation in the course of a metasomatic enrichment event whereby successive inclusions become

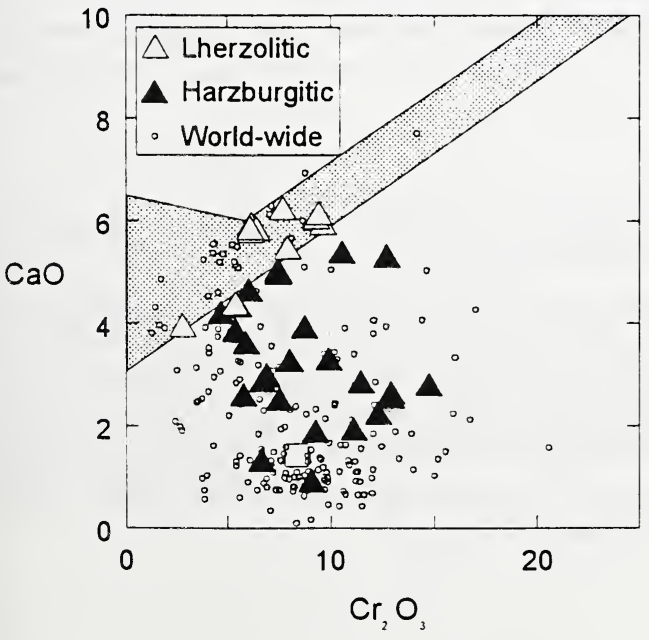

Fig. 1. Diagram of $\mathrm{CaO}$ versus $\mathrm{Cr}_{2} \mathrm{O}_{3}$ (wt \%) in garnet with the Iherzolite field (shaded area) as defined by Sobolev et al. (1973). The open square refers to the harzburgitic garnet coexisting with a $\mathrm{SiO}_{2}$-phase inclusion (see text). Small open circles refer to our world-wide inclusion database (for references see Stachel and Harris, 1997). 
8384858687888990919293949596

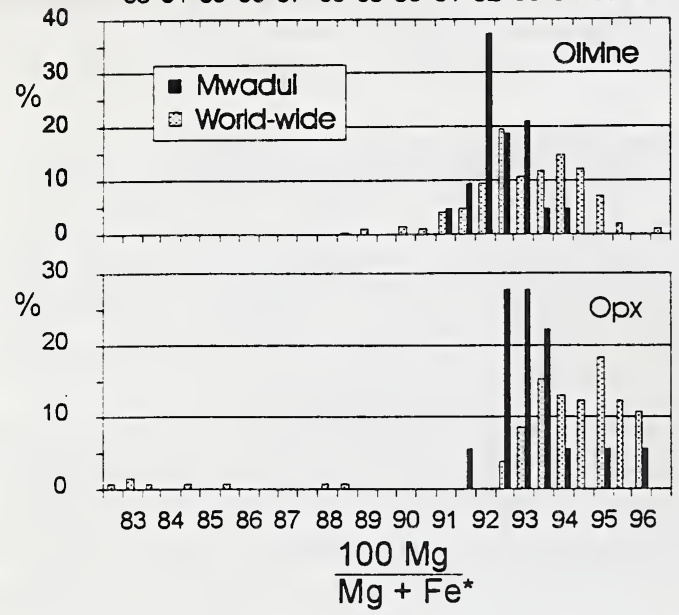

Fig.4. Histogram (frequency in \%) of the molar Mg-numbers of olivine and orthopyroxene inclusions from Mwadui and from world-wide sources (world-wide inclusion data base: 217 olivines and 135 orthopyroxenes). The unusually high proportion of Iherzolitic inclusions for Mwadui is well displayed in generally low Mg-numbers, relative to the world-wide database.

richer in Fe. Further indications of large variations in the chemical environment during diamond growth may come from the coexistence of a $\mathrm{SiO}_{2}$-phase and harzburgitic garnet in the same diamond. An ultra-deep ( $>400 \mathrm{~km}$ ) origin of this paragenesis, as suggested by Kopylova et al. (1997), is excluded because of the non-majoritic nature of the garnet. However, localised extreme carbonation of mantle peridotite could eventually also result in the formation of a free $\mathrm{SiO}_{2}$-phase (Wyllie and Huang, 1976). The additional observation of a lone dolomite inclusion fits into such a scenario of high, localised $\mathrm{CO}_{2}$ influx.

In addition to the standard peridotitic mineral suite Mwadui diamonds contain a number of rare or unusual inclusions. Among these is an ilmenite group inclusion with unprecedented eskolaite content (14.5 mol\%) occurring together with harzburgitic garnet and olivine. For upper mantle derived ilmenites high chromium contents are characteristic for ilmenite-spinel ( \pm rutile) assemblages formed by subsolidus reduction but rarely exceed $10 \mathrm{~mol} \% \mathrm{Cr}_{2} \mathrm{O}_{3}$ (Haggerty, 1991). In two diamonds magnetite inclusions were observed with sub- $\mu \mathrm{m}$ exsolution lamellae of a high silica phase (possibly fayalite, Fig. 3). New experimental data on the binary system $\mathrm{Fe}_{2} \mathrm{SiO}_{4}-\mathrm{Fe}_{3} \mathrm{O}_{4}$ (Woodland, 1997) indicate that at pressures above $30 \mathrm{kbar}\left(\right.$ at $1100^{\circ} \mathrm{C}$ ) an intermediate spinelloid phase appears. Assuming that the spinelloid phase is not restricted to $\mathrm{Mg}$-free systems, this result excludes coexistence of magnetite and olivine in the diamond stability field.

The presence of two diamonds, one containing inclusions of moderately majoritic eclogitic garnet, the other of ferropericlase, may indicate a small diamond contribution from the sub-

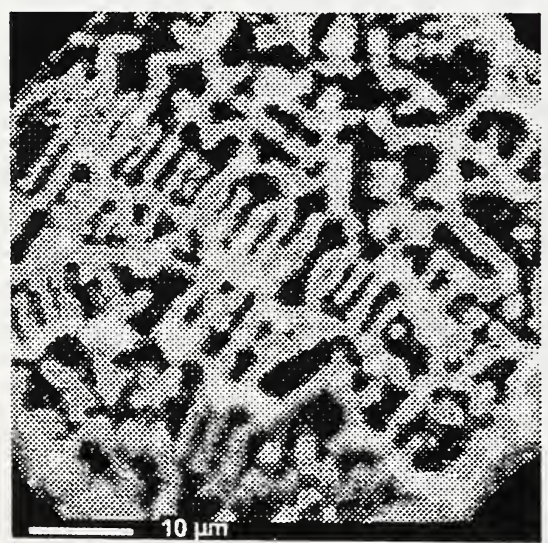

Fig. 3. Image of the distribution of $\mathrm{Si}$ in magnetite inclusion MW96-136. A matrix of $200 \times 200$ points (0.1 seconds per point) was collected as beam scan at $15 \mathrm{kV}$ and $20 \mathrm{nA}$. The contrast was enhanced after data collection by histogram equalisation, for noise reduction a median filter was applied. Bright colours imply high Si contents. The grain boundaries can be seen in the four corners of the image. Grain diameter is about $70 \mu \mathrm{m}$. 
lithosphere. Although the evidence of a single ferropericlase inclusion is ambiguous, its presence might testify to a lower mantle origin. An inclusion of native iron rimmed by wustite (plus a coexisting inclusion of magnetite) also might be indicative of an ultra-deep origin and indicates rather large variations in oxygen fugacity from below WI ( $\mathrm{FeO}-\mathrm{Fe})$ to above $\mathrm{MW}\left(\mathrm{Fe}_{3} \mathrm{O}_{4}-\mathrm{FeO}\right)$.

To account for the disequilibrium conditions during diamond formation beneath Mwadui, we conclude that diamonds grew in metasomatic fronts, where steep compositional gradients existed and where carbon was deposited as diamond from redox reactions between the metasomatic fluid or melt and the peridotitic wall rocks.

\section{References}

Brey, G.P., and Köhler, T., 1990, Geothermobarometry in four-phase lherzolites II. New thermobarometers, and practical assessment of existing thermobarometers: J. Petrol., v. 31, p. 13531378.

Dawson, J.B., 1992, Neogene tectonics and volcanicity in the North Tanzania sector of the Gregory Rift Valley - contrasts with the Kenya sector: Tectonophysics, v. 204, p. 81-92.

Gobba, J.M., 1991, The geology and mineralogy of some kimberlites in the Mwadui area: 5 . International Kimberlite Conference, Araxá 1991, Extended Abstracts, CPRM Spec. Publ., v. 2/91, p. $116-118$.

Haggerty, S.E., 1991, Oxide mineralogy of the upper mantle, in Lindsley, D.H., ed., Oxide minerals: petrology and magnetic significance: Reviews in Mineralogy, v. 25, p. 355-416.

Harley, S.L., 1984, An experimental study of the partitioning of iron and magnesium between garnet and orthopyroxene: Contrib. Mineral. Petrol., v. 86, p. 359-373.

Janse, A.J.A., 1994, Is Clifford's rule still valid? Affirmative examples from around the world, in Meyer, H.O.A., and Leonardos, O.H., eds., Diamonds: characterization, genesis and exploration: Brasilia, CPRM Spec. Publ., v. 1/B Jan/94, p. 215-235.

Kelemen, P.B., and Hart, S.R., 1996, Silica enrichment in the continental lithosphere via melt/rock interaction: Goldschmidt Conference, Heidelberg 1996, Journal of Conference Abstracts, v. 1-1, p. 308.

Kopylova, M.G., Gurney, J.J., and Daniels, L.R.M., 1997, Mineral inclusions in diamonds from the River Ranch kimberlite, Zimbabwe: Contrib. Mineral. Petrol., v.129, p. 366-384.

ONeill, H.St.C., 1980, An experimental study of the iron-magnesium partitioning between garnet and olivine and its calibration as a geothermometer: corrections: Contrib. Mineral. Petrol., v. 72, p. 337.

O'Neill, H.St.C., and Wood, B.J., 1979, An experimental study of the iron-magnesium partitioning between garnet and olivine and its calibration as a geothermometer: Contrib. Mineral. Petrol., v. 70, p. 59-70.

Sobolev, N.V., Lavrent'ev, Yu.G., Pokhilenko, N.P., and Usova L.V., 1973, Chrome-rich garnets from the kimberlites of Yakutia and their paragenesis, Contrib. Mineral. Petrol., v. 40, p. 39-52.

Stachel, T., and Harris, J.W., 1997, Syngenetic inclusions in diamond from the Birim Field (Ghana) - a deep peridotitic profile with a history of depletion and re-enrichment: Contrib. Mineral. Petrol., v. 127, p. $336-352$.

Woodland, A.B., 1997, The system $\mathrm{Fe}_{2} \mathrm{SiO}_{4}-\mathrm{Fe}_{3} \mathrm{O}_{4}$ : phase relations to $9 \mathrm{GPa}$ and molar volumes of spinel solid solutions: EOS Transactions of the American Geophysical Union, v. 78, p. 766.

Wyllie, P.J., and Huang W.-L., 1976, Carbonation and melting reactions in the system CaO-MgO$\mathrm{SiO}_{2}-\mathrm{CO}_{2}$ at mantle pressures with geophysical and petrological applications: Contrib. Mineral. Petrol., v. 54, p. 79-107. 